Moral Connections: The Relationship between Abortion and Fetal Tissue Research*
The Linacre Quarterly 2019, Vol. 86(2-3) |76-18| (C) Catholic Medical Association 2019 Article reuse guidelines: sagepub.com/journals-permissions DOI: 10.1 177/00243639|9855894 journals.sagepub.com/home/lqr

\author{
Andrew F. Shorr, MPH'
}

Editor's note: The connections among aborted fetal tissue, medical research, conscience, and the delivery of health care have been drawn into sharp focus in recent years because of vaccines that are prepared from cell lines derived from fetal tissue. To aid our readers in understanding the historical context of this problem and to assist them in addressing this issue with their patients, we reprint this article from 1994, along with the statement from the Pontifical Academy for Life regarding the use of aborted tissues in vaccine production.

The author's most recent article, "AIDS and the FDA: An Ethical Case for Limiting Patient Access to Experimental Therapies," appeared in the September 1992 issue of IRB: A Review of Human Subjects Research.

Human fetal tissue holds much promise as a therapy for a number of intractable conditions. ${ }^{1}$ In animals, researchers have shown that the transplantation of fetal tissue into select regions of the brain can alleviate the symptoms of Parkinsonism. Moreover, scientists from both Sweden and Mexico have transplanted fetal neural tissue into the brains of patients with Parkinson's disease. These efforts have not only ameliorated the signs of the disease but also appear to slow its progression. Experts in this field further believe that a number of other disorders will respond to human fetal transplants. Likely candidates for fetal tissue therapy include: DiGeorge's syndrome, diabetes mellitus, Huntington's disease, and Alzheimer's disease. No cure exists for any of these diseases and none, other than fetal tissue therapy, appear on the horizon.

In light of these facts, many scientists have pushed ahead with research in this field. Individuals in both the lay and professional communities, however, have raised a number of ethical concems. ${ }^{2}$ Their objections focus on the link between the therapy and the source of the fetal tissue - elective abortions. Since material from spontaneous abortions likely contains fetal pathology, such tissue is medically unacceptable for transplantation. Thus, material salvaged from induced abortions primarily serves as the only source for fetal tissue. Opponents of fetal tissue transplantation research assert that one cannot weigh the ethical questions involved in this issue without evaluating the moral status of induced abortion. Proponents of this endeavor, though, state that fetal tissue experimentation and abortion are "morally separate." For example, John Robertson writes that "One's views on abortion need not determine one's answer to this question, because the abortion and the subsequent transplant are clearly separate."3 Moreover, they point to the recommendations of the National Institutes of Health (NIH) Human Fetal Tissue Transplantation Panel. Advocates of fetal tissue research claim that the guidelines for fetal transplantation proposed by this

\footnotetext{
I The Johns Hopkins School of Hygiene and Public Health, Baltimore, MD, USA

*This article appeared in the Linacre Quarterly (February 1994), volume 6I, Number I
}

Corresponding Author:

Email: lq@cathmed.org 
commission ensure that efforts to utilize fetal tissue as therapy will remain separate from the issue of abortion. An examination of the impact fetal tissue investigations will have on the rate of abortions, of ethical questions regarding consent, and of issues of complicity, though, reveals that in order to determine the ethics of fetal tissue research, one must examine the moral status of abortion.

\section{The Abortion Rate}

Those who believe that human fetal transplantation is unethical state that such research will increase the number of abortions performed in this nation. Success in this area will enlarge the demand for fetal tissue which, in turn, will necessitate more abortions. Additionally, women who might not have otherwise opted for abortion will choose this alternative once the government sanctions fetal tissue research. For example, some women who are pregnant might view abortion differently because they feel either that some "good" could be achieved through their actions or that donation will alleviate their feelings of guilt. The existence of fetal therapy will also create an incentive for women who are not pregnant to become so and then decide to abort. Such women may have become pregnant in order to either donate fetal tissue to a relative in need of a fetal tissue treatment or in order to receive monetary remuneration. On a societal level, fetal tissue efforts will change general attitudes about abortion. Now often viewed as a tragic event, abortion may come to be seen as a positive attempt to improve the plight of others suffering from horrible diseases. Thus, since fetal tissue research and therapy will alter both rates and perceptions of abortion, it is necessary to evaluate the morality of abortion if one wishes to determine if fetal tissue therapy is ethical.

Those who claim that fetal tissue research and transplantation are ethical offer several responses. First, in this nation over 1.3 million induced abortions are performed each year. ${ }^{4}$ Hence, a plethora of fetal tissue exists. Second, under the proposed NIH guidelines, women will be informed about the option to donate fetal tissue only after they have chosen to abort. As a result, the decision to abort will remain isolated from the decision to donate the resulting fetal tissue. Moreover, proponents of fetal tissue research believe that "the reasons for terminating a pregnancy are complex, varied, and deeply personal," and that the existence of fetal tissue research and therapy will not alter this fact. ${ }^{5}$ Third, in order to ensure that one does not become pregnant solely for the purpose of aborting and then donating fetal tissue, women will not be allowed to designate a recipient for the fetal tissue. Fourth, as with the donation of organs under the Uniform Anatomical Gift Act (UAGA), it will be illegal either to pay those who donate or to purchase fetal tissue. These barriers should serve to guarantee that questions about abortion do not cloud the ethical issues concerning fetal tissue research.

The argument that the current number of abortions will cover the possible demand for fetal tissue suffers from several flaws. Of the 1.3 million abortions performed annually in this nation, neural tissue from approximately only 90,000 abortuses will be available for research and transplantation efforts. ${ }^{6}$ Not all abortions occur during points in gestation when fetal tissue is appropriate for transplant, partially accounting for the over $90 \%$ drop in the useable amount of fetal material. Moreover, the most often employed method of termination, suction and curettage, makes the identification of fetal neural tissue difficult. Approximately 60,000 Americans presently suffer from Parkinson's disease and many more are afflicted by Huntington's disease and Alzheimer's disease. ${ }^{7}$ Given 1) the current rate of abortions and 2) the state of abortion technology, the demand for fetal tissue will outstrip supply. The possibility that research will reveal that only fetal material with specific attributes will be acceptable for implantation further complicates matters. For example, envision a scenario similar to the situation surrounding the Yew tree. ${ }^{8}$ This plant is the sole source for a promising chemotherapeutic agent for breast cancer. However, to produce one dose of this drug requires the destruction of several hundred Yew trees. Scientific concerns about the histocompatibility of fetal tissue underscore the significance of this point and reinforce the possibility that fetal tissue will remain a scarce resource unless, in the future, more elective abortions occur.

Assertions that the proposed NIH guidelines, which attempt to isolate the decision to abort from the option of donation, will morally separate abortion and fetal tissue efforts are also faulty. Allowing clinic staff to "officially" inform a woman about the option of donating the fetal tissue only after she has consented to an abortion views the determination to abort too narrowly. Media coverage of fetal tissue experimentation will make certain that women are cognizant of this alternative as they grapple with the question of elective abortion. This, in turn, will skew the decision-calculus of some. In other words, although the potential for donation may not serve as the primary reason for an abortion, it certainly will influence the reasoning of some women. Additionally, sterility requirements "impose 
the practical necessity of arranging for fetal tissue donation before an abortion while the fetus remains alive." 9 This again demonstrates the difficulty in insulating the alternative to abort from the possibility of donation. In essence, this technical demand further undercuts the ability to insulate the issue of abortion from the acceptability of fetal tissue research. Even Robertson, a strong advocate for fetal tissue transplantation, states that: "Perhaps a few more abortions will occur because of the general knowledge that tissue can be donated for transplant." ${ }^{10}$ Robertson further writes that this will not be and should not be a "significant" barrier to fetal tissue research. However, determining "significance," in this instance, presupposes a decision on the morality of abortion.

Furthermore, attempts to prohibit women from indicating a recipient for the resulting fetal tissue contradict the assertion that abortion and fetal tissue transplantation research are morally separate. The aim of such regulations is to prevent women from becoming pregnant for the sole purpose of providing fetal material. Thus, a woman's motive in opting for an abortion appears to be morally relevant. This connection underscores the ethical bridge between abortion and fetal tissue therapy. As James Childress, a proponent of fetal tissue efforts, admits: "The rationale [for these rules includes] ... concerns about the morality of abortion." 11 One must also consider the possibility that the proposed recommendations will prove ineffective. For example a New York Times report indicates that at least several women have already become pregnant in order to be able to donate fetal tissue to a relative in need of a transplant. ${ }^{12}$ To measure the ethical importance of this question, one must evaluate the moral nexus between abortion and fetal tissue therapy.

The belief that banning the sale and purchase of fetal tissue will insulate abortion and fetal transplantation research also labors under several difficulties. First, supporters of fetal tissue experimentation state that few, if any women, would become pregnant in order to sell fetal tissue. They believe that the decision to become pregnant is complex and that monetary factors will not skew an individual's choice. Women, however, are willing to become surrogate mothers in exchange for payment. ${ }^{13}$ Moreover, in terms of health risks, full-term pregnancy and delivery are more dangerous endeavors than an early abortion. Pregnancy for purposes of fetal tissue donation may, therefore, seem a more appealing alternative. Concerns about the commercialization of surrogacy thus appear less significant than the potential for the commercialization of fetal tissue, especially if medical technology advances in a way which makes possible the identification of women who might have "scarce" fetal resources needed for particular medical conditions.

Second, black markets, although limited, exist for adult organs and there is no reason to assume that they will not also exist for fetal tissue. Third, even if proposed recommendations effectively prevent the direct sale of fetal products, the demand for fetal tissue is likely to result in the creation of shadow markets. In this case, rather than paying a woman for the tissue of the abortus, those attempting to harvest fetal remains would perform the abortion at no charge. If shadow markets operate, women, who for financial reasons are unable to otherwise obtain an abortion, might choose this option. This matter is particularly pressing since the NIH guidelines appear to sanction the creation of shadow markets; they allow those performing fetal tissue implants to recoup the costs associated with the retrieval of fetal tissue. In other words, it appears that the recommended regulations may, in effect, allow for the existence of distinct but equivalent forms of financial incentives with little or no significant moral difference. Put simply, the contention that fetal tissue research will not affect the rate of abortion is not only flawed, but it also fails to rebut the existence of a moral connection between fetal issue transplantation and abortion.

\section{Consent}

Questions regarding informed consent and the use of fetal tissue for transplantation additionally reinforce the ethical link between fetal tissue research and the moral status of abortion. Opponents of fetal tissue research argue that these efforts are unethical, in part, because it is not possible to obtain proper consent for the use of the fetal remains. In short, there is no one who can ethically authorize the utilization of the fetal cadaver for such undertakings. The mother of the fetus, by opting to end its life, abrogates her authority over its disposal. Since she has decided to destroy the fetus, she cannot act as its proxy. This claim rests on the belief that one who serves as an agent in another's death cannot represent the decedent's interests. Prohibitions against the execution of an estate by a person who murders that individual embody the logic of these claims. Moreover, in the instance of induced abortion, no other person is available to provide consent. The father of the fetus, for instance, is often absent. Advocates of fetal tissue research provide several responses to these assertions. Their arguments, however, fail to refute the existence of a moral association between fetal research and abortion. 
First, some assert that consent is not at issue since the mother of the aborted fetus has special interests regarding the disposition of the fetal tissue. The existence of these interests allow her to consent to the donation of the fetal remains. This proposition, though, sidesteps the issue of elective abortion. Simply because someone may have an interest in the final disposition of a cadaver does not necessarily imply that he/she has the right to determine how that cadaver is treated. As a counter-example, imagine an impoverished husband, in dire need of funds, whose wife has just died. In order to raise cash, the husband could attempt to sell the vital organs of his dead wife. This action is forbidden both ethically and legally. Moreover, if a person, for emotional reasons, wished to have his mother's dead body stuffed and mounted, he/she too should be ethically prohibited from doing so. ${ }^{14}$ In essence, the response that a next-of-kin's personal interests provide him/ her with the authority to consent to the disposition of a cadaver ignores the fundamental question of why consent is ethically required. At issue in each of these examples is a more fundamental question: Do one's special interests, which translate into a right to make these decisions about the disposal of remains, depend upon the ethical character of the choice the agent proposes to make or, rather, are they based on the underlying ethical nature of the acts and the motivations which lead up to there being remains of which to dispose?

A second reply focuses on the interests of the fetus and state that these interests terminate with fetal death. One only need look to the law to understand the defect with this assertion. For instance, the law posthumously protects one's patent rights and, in some cases, his/her reputation. Additionally, to assert that the interests of the fetus end with its demise while those of adults do not terminate with death implies that fetal deaths are of different significance than adult deaths. Such a conclusion indicates a decision about the morality of abortion and further solidifies the connection between abortion and fetal tissue research and transplantation.

Benjamin Freedman suggests a third response: the main ethical question is not about consent but is about respectful disposition of dead bodies. ${ }^{15}$ Unlike adult cadavers which will be buried in public graves, fetal tissue from abortions is treated as if it were organic trash. Fetal remains are burned along with amputated limbs and pathology biopsies. According to Freedman, the use of fetal tissue as a medium for medical therapy is a more respectful alternative. This argument, though, does not acknowledge the reality that only a small fraction of fetal tissue will be used for research experiments and transplantation efforts. ${ }^{16}$ Furthermore, to admit that a fetal cadaver merits some degree of respect suggests that the abortus is not a mere collection of cells and tissue. Rather, such a justification insinuates that the fetus is an entity to which others owe respect - a judgement about the moral position of the fetus. Additionally, those who reject a special obligation to show respect to the dead have made the judgement that the question of fetal tissue donation does not involve human persons to which we otherwise would need to show respect. This only reveals that one's view on this matter may already depend heavily upon some notion about the morality of abortion and whether the loss of human life is at stake.

John Robertson offers a fourth counterargument. Robertson believes that we defer to the next-of-kin about the disposition of remains not because the kin are appropriate proxies but because we want to acknowledge their relationship with the deceased. ${ }^{17}$ If consent were the crucial issue, he contends, then why does the state occasionally overrule the desires of the family? When the conditions surrounding a death are suspicious, for example, the government can order an autopsy, irrespective of the wishes of the family. In essence, Robertson concludes that consent is a non-issue. This proposition, though, fails for two reasons. First, an individual may determine, prior to death, the final disposition of his/her cadaver. If the sole concern were the relationship between the kin and the decedent, this alternative would not exist. Second, the right of the state to order an autopsy against the wishes of the family indicates that consent can be weighed against other concerns, not that it is of no significance.

\section{Complicity}

In addition to concerns about a potential increase in the number of abortions and questions of consent, those who oppose fetal tissue research believe that such efforts make the scientists involved complicitous in the act of abortion. In short, these researchers become parties, after the fact, to the destruction of the fetus. Furthermore, through their collaboration with the abortion industry, those involved in fetal tissue research morally align themselves with the abortion. Those who suggest that fetal tissue research and abortion are morally connected base their allegation of complicity on the belief that one can be complicitous in both active and passive fashions. That a fetal tissue researcher may not actively applaud abortion 
does not negate his/her complicity. Burtchaell takes this argument one step further and raises the specter of the Nazi atrocities. ${ }^{18}$ According to Burtchaell, just as one would raise moral objections to using data gathered on concentration camp survivors, one should also object to fetal tissue research and transplantation. Persons contending that abortion and fetal tissue research are ethically unconnected offer several answers to these charges.

A typical response emphasizes the link between complicity and cause. For example, Freedman writes that causes must precede effects; and thus, one cannot become complicit by failing to distance him/herself from the act in question. ${ }^{19}$ Such a contention, though, denies the central issue: it is possible to be complicit after the fact. The person who abets a crime after its commission also transgresses moral norms. To buttress this point, Burtchaell provides an interesting analogy: Many would raise moral objections to utilizing for research the bodies of black South Africans who died under suspicious circumstances - even though using these cadavers did not directly lead to any deaths. ${ }^{20}$

Advocates of fetal tissue transplantation also contend that such research is separated in both time and space from abortion. Scientists cannot be complicit in an abortion which they had no knowledge of and did not request. Robertson further uses this argument to counter the Nazi analogy. ${ }^{21}$ Robertson's proposition, however, does not disprove the existence of an ethical link between fetal research efforts and abortion. He assumes that the "abortions occur for reasons unrelated to donation." 22 By implication, the situation would be different if an abortion took place in order to make fetal tissue available for transplant Thus, both the intent of the women and the abortion become variables in the moral equation. Furthermore, temporal distance, alone, fails to relieve one of the burdens of complicity. If person $X$, for instance, 1)stole stock from Y, 2)bought a house with those funds after liquidating the stock, and 3)left the house to his/her heirs, moral principles would require that $X$ 's children, irrespective of their distance from the original act, remunerate Y's offspring (assuming they become aware of how $\mathrm{X}$ initially obtained the money). More importantly, participants in fetal tissue experiments, through their efforts, help to legitimize and perpetuate abortion. As a result, although scientists may be, per se, insulated from the ethical ramifications of any particular abortion, they nonetheless remain complicit.

The NIH panel report provided an alternative rejoinder to the question of complicity. The commission noted that although complicity may be a legitimate concern, the legality of abortion and the vigorous debate over the morality of abortion weaken such claims. On the other hand, this logic also implies that if abortion were clearly morally wrong then one would have to reinvestigate the ethical issues surrounding fetal tissue research. Such implications underscore the moral relationship between abortion and fetal tissue research. Moreover, because the morality of abortion remains a contentious issue does mean that the truth remains out of reach. Rather, it suggests that some individuals in this discussion are incorrect in their conclusions. In other words, disagreement over the ethics of abortion does not indicate that abortion is acceptable. This form of argument also raises a further question: Would it be appropriate to use fetal tissue from abortions induced for purposes of sex selection? Almost all ethicists involved in this issue concur-abortions for sex selection are unethical. For example, John Fletcher, an ardent supporter of fetal tissue transplantation research, writes that sex selection abortions are unacceptable: "The medical profession has a responsibility to take a firm stand now against sex selection." 23 The possibility of fetal material coming from abortions for which there is a broad consensus as to their unethical nature highlights the moral link between abortion and fetal tissue transplantation efforts.

The most compelling response to charges of complicity, though, is found in another analogy. Surely, transplant surgeons are not accomplices to murder simply because they remove organs from homicide victims. ${ }^{24}$ A deeper analysis, however, shows this comparison to be inapt. Simply put, it begs the question of the intent of the murderer. What if the physician knew that the perpetrator killed the decedent solely to create a source of organs for transplant? In this instance, if the doctor opted to salvage organs from the victim, many would consider him/her to be complicit in the act of murder. Similarly, to determine the ethics of fetal tissue research, one must consider the intentions of a woman choosing elective abortion and its moral consequences.

\section{Conclusion}

Is it possible to insulate morally abortion from fetal tissue research? A review of the link between fetal tissue experimentation and the rate of abortion, of the issue of consent, and of concerns over complicity demonstrates that the two are necessarily connected. Moreover, the responses of advocates of fetal tissue transplantation fail to disprove the presence of a moral nexus between fetal tissue research and 
abortion. Therefore, to determine if fetal tissue investigations are ethical, one must evaluate the moral status of abortion.

\section{Acknowledgments}

The author would like to thank Madison Powers, James Burtchaell, and John Fletcher for helpful comments on earlier drafts of this manuscript.

\section{Declaration of Conflicting Interests}

The author(s) declared no potential conflicts of interest with respect to the research, authorship, and/or publication of this article.

\section{Funding}

The author(s) received no financial support for the research, authorship, and/or publication of this article.

\section{References}

1. For a brief overview of current research in this area see: Strong, Carson. "Fetal Tissue Transplantation: Can it Be Morally Insulated From Abortion.” Journal of Medical Ethics; 1991, 17: p. 70. I am indebted to this paper for much of the structure of my argument.

2. For a synopsis of the objections to fetal tissue research see: Burtchaell, James T. "Case Study: University Policy on Experimental Uses of Aborted Fetal Tissue." IRB: A Review of Human Subjects Research; 1988, 10: pp. 7-11.

3. Robertson, John A. "Rights, Symbolism, and Public Policy in Fetal Tissue Transplants." Hasting Center Report; 1988, 18: p. 6.

4. Childress, James F. "Ethics, Public Policy, and Human Fetal Tissue Transplantation Research.” Kennedy Institute of Ethics Journal; 1991, 1: p. 97.
5. Text of the NIH panel report cited in Childress, p. 105

6. Fine, Alan. "The Ethics of Fetal Tissue Transplants." Hastings Center Report; 1988, 18: p. 6.

7. Fine, p. 6 .

8. I am indebted to Madison Powers for this insight.

9. Burtchaell, James T. "The Use of Aborted Fetal Tissue in Research: A Rebuttal." IRB: A Review of Human Subjects; 1989, 11: p. 9.

10. Robertson, "Rights, Symbolism, and Public Policy," p. 7.

11. Childress, p. 106.

12. Lewin, Tamar. "Medical Use of Fetal Tissue Spurs New Abortion Debate." New York Times; August 16, 1987, p. 1.

13. By this statement, I do not intend to imply that financial issues are sole factors that a woman considers when deciding whether to become a surrogate.

14. A more complete discussion of this point is beyond the scope of this paper.

15. Freedman, Benjamin. "The Ethics of Using Human Fetal Tissue." IRB: A Review of Human Subjects Research; 1988, 19: p. 3.

16. String, p. 72.

17. Robertson, John A. "Fetal Tissue Transplant Research is Ethical." IRB: A Review of Human Subjects Research; 1988, 10: p. 6.

18. Burtchaell, James T. "Case Study: University Policy on Experimental Use of Aborted Fetal Tissue," p. 10.

19. Freedman, p. 3.

20. Burtchaell, "Case Study: University Policy on Experimental Use of Aborted Fetal Tissue," p. 11.

21. Robertson, "Fetal Tissue Transplant Research is Ethical," p. 7.

22. Robertson, "Fetal Tissue Transplant Research is Ethical," p. 7.

23. Fletcher, John and Wertz, Dorthy. "Fatal Knowledge? Prenatal Diagnosis and Sex Selection." Hastings Center Report; 1989, 19: p. 21.

24. Robertson, "Fetal Tissue Transplant Research is Ethical," p. 6. 